\title{
Tourism sensitivity to natural disaster: a case study of Ranau Earthquake 2015
} \author{
Teck Ling 5, Mohd Hamdan Ahmad 6, Syumi Rafida Abdul Rahman ${ }^{7}$ \\ 1 Universiti Teknologi Malaysia; akmohdrafiq@utm.my \\ 2 Universiti Teknologi Malysia; pcleng2@utm.my \\ 3 Universiti Teknologi Malysia; solehin@utm.my \\ 4 Universiti Teknologi Malysia; noradila@utm.my \\ 5 Universiti Teknologi Malysia; gabriel.ling@utm.my \\ 6 Universiti Teknologi Malysia; b-hamdan@utm.my \\ 7 Alambina Design Sdn. Bhd; syumirafida@gmail.com \\ * Correspondence: akmohdrafiq@utm.my
}

Ak Mohd Rafiq Ak Matusin ${ }^{*}$, Pau Chung Leng ${ }^{2}$, Muhamad Solehin Fitry Rosley ${ }^{3}$, Noradila Rusli ${ }^{4}$, Gabriel Hoh

\begin{abstract}
Despite increased global interest in the impacts of natural disasters on tourism, less study executes exploring how tourism sensitivity is addressed at the destination level. Generating a link between tourism and natural disaster management is vital in places that rely heavily on tourism and are prone to natural hazards. Ranau, Sabah (Malaysia) is one of the disaster-prone tourists' destination area. Hence, this paper applies the case study of Ranau earthquake 2015 to explore tourism sensitivity towards natural disasters. A qualitative of in-depth interview is applied to acquire information needed from the Ranau tourism entrepreneurs and operators. To analyse the qualitative data, a thematic analysis is conducted. Overall findings show that tourism activity in Ranau are identified to be sensitive towards the 2015 earthquake with a significant percentage of sensitivity level on two elements. These elements are known as Source and Power. The Source element includes tourism products, size of business, development, and natural disasters management with a significant sensitivity compared to the Power element (social capital). This provides insight to the need of specific tourism system adaptation as response to the earthquake and considering the integration of natural disaster management into tourism development to enhance long term sustainability.
\end{abstract}

Keywords: sustainable tourism; tourism sensitivity; tourism vulnerability; natural disaster; earthquake

\section{Introduction}

Tourism is an economic-vital growing industry. International tourists' arrival shows continuous increases in numbers from 2017 to 2018 and this momentum is expecting to keep growing (World Tourism Organization 2018). This contributes to currency exchange activities (WTO 2013), thus enhance social and economic development, especially to the community that relies heavily on tourism as their livelihood resources (Guo et al. 2018). At the same time, tourism also no exception to deal with a natural disaster such as an earthquake. Numerous studies have provided empirical evidence on the impact of the earthquake on tourism activity and its sustainability (Kato 2017, Calgaro et al. 2014, Orchiston 2013, Tsai and Chen 2010). In response, natural disaster management incorporated into tourism as one of the fundamental elements to implement sustainable tourism development (Orchiston 2012). In tourism context, natural disaster management is a tourism organisation response to natural disaster to reduce the destruction and enhance restoration process through development strategic of natural disaster management (Faulkner 2001). Adger (2006) added the first step in natural disaster management in achieving sustainable development is through vulnerability study. 
In natural disasters context, vulnerability is a vulnerable state of a community, system or asset to the destruction of natural disasters (UNIDSR 2017). Vulnerability approach particularly is known as a study of exposing unit (household, human, ecosystem, community) vulnerable to hazards due to the exposure of shock or stress and the capability (or incapability) of the unit to act, recover or adjust (Kasperson et al. 2012). In the tourism context, the vulnerability approach plays a vital role in building a method to identify the crises and distinguish the level of risks in community-based tourism landscape systematically and effectively (Tsao and Ni 2016). Besides, vulnerability approach also helps tourism to access and distribute the revenues from tourism activities sustainably especially when it is needed by tourism community to cope and resists for adjustment during crises (Calgaro and Lloyd 2008).

In case of Ranau earthquake, this natural disaster strikes on June 2015 with a magnitude of 6.0 Ritcher, scale VII (very strong) (United State Geological Survey 2015). The epicentre is located approximately $7 \mathrm{~km}$ NNE of Kundasang Town and $13 \mathrm{~km}$ NW of Ranau Town and strike at a depth of $10 \mathrm{~km}$ (Tongkul 2015) - Figure 1. This is the strongest and first earthquake ever recorded in Malaysia (Tongkul et al. 2017). This earthquake's impacts include infrastructure destruction such as school, mosques, church, hostel and natural environment including river, climbing trail, flora and fauna (Tongkul et al. 2017, Tongkul 2015). Several climbers also reported dead, and many of them were trapped at the summit of Mount Kinabalu during the earthquake due to cut off of climbing trails (Matusin et al. 2019).

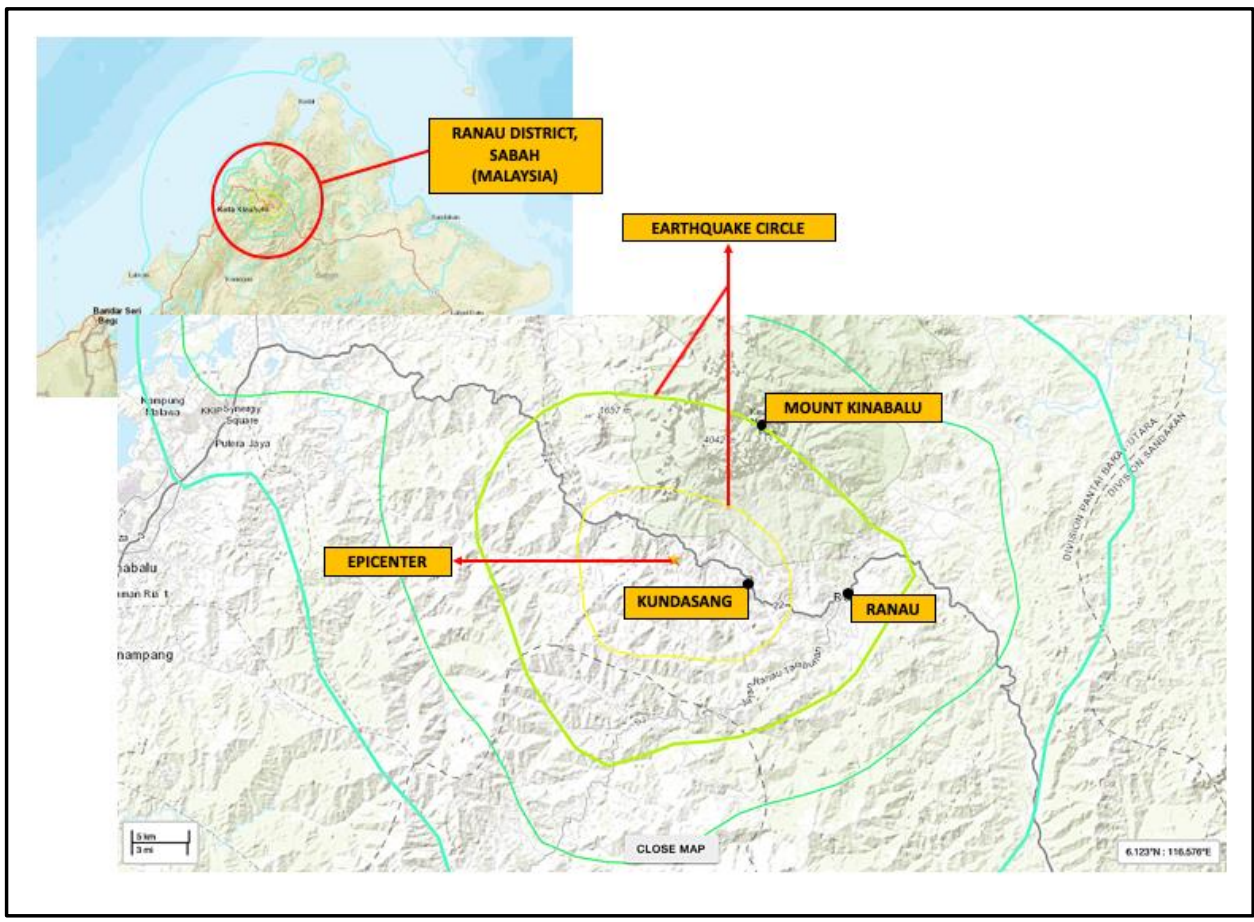

Figure 1. Ranau earthquake 2015 map (modified)

Despite the impacts of Ranau earthquake 2015, however, less study has been focused on Ranau sensitivity in the context of tourism. In fact, tourism is the main economic sector in Ranau development and a socio-economic resource (Ranau District Office 2011, 2015). While Sabah Park (2018) reported that the numbers of visitors to Kinabalu Park were declined after the earthquake struck in June 2015. The statistics indicate a negative impact of the earthquake on local tourism activity in Ranau. At the regional level, there is no involvement of natural disaster management in tourism planning including Ranau tourism to foster long term sustainability of tourism sector in Sabah state (Town and Regional Planning Department of Sabah 2016), which affecting the capability of Ranau tourism to 
deal with vulnerability especially natural disaster. Therefore, this paper is aimed to explore tourism sensitivity of Ranau to 2015 earthquake at the destination level.

\section{Literature Review}

\subsection{Vulnerability Approach and Tourism}

In sustainability science perspective, vulnerability is defined as a contextualised human-environment system that influenced by the interaction between biophysics, sociopolitic, economy, institution and technology condition (Turner et al. 2003). This perspective provides meaningful exploration of different place-specific function and individual situations that create a different level of vulnerability and resilience (Rigg et al. 2008). It also helps individuals and communities respond to the changes by effectively facing vulnerability drivers (O'Brien 2006). Vulnerability concept later expanded with the incorporation of system approach, which defined vulnerability as a conceptualised and multidimensional asset in a human-environment system (Eakin and Luers 2006). Basically, the system approach explains the component characteristics (including human as active actors) play essential role in shaping a system. At the same time, this approach scrutinises each component's functionality. It explores the dynamic of component dependency with relation factor and feedback from the changes (Hay 2006). Consequently, the incorporation of the system approach and vulnerability creates a concept of Vulnerability Approach. Kasperson et al. (2012) defined the vulnerability approach as a study of an exposed unit (household, human group, ecosystem, community) vulnerable to hazards due to exposure to shock or pressure as well as the capability (or incapability) of exposed unit to response, recover or adjustment holistically.

Vulnerability approach composes a sophisticated understanding of context, agency, equity, justice and Power (Eakin and Luers 2006). Fundamental of this understanding is a multi-scale socio-politic process that shapes the reaction towards the risk and changes and its form, which occurred in the socio-ecological system, including the influences underlying system strength, value, and ideology knowledge and culture norms (Miller et al. 2010). Besides that, vulnerability approach also encapsulates resistance to change, trading within humans, system, level and scale, and narrative used by actor and institution to gain credibility, legitimation, authority and Power (Berkhaout 2008). This explains the role plays by human as an actor in influencing system vulnerability. Importantly, this approach is normative for risk reduction activity, which translated to maintain the balance in the existing socio-ecology system (Adger 2008).

In tourism context, there are four advantages of system approach incorporation into tourism (1) system approach helps to identify stakeholder in a system, (2) to explain the advantages of networking and interaction in determining different results (positive and negative) in each different actors either within or crossing system boundaries, (3) to identify the effect of shock or stress that transferred into system boundary through organisation relationship, (4) to analyse factors that influenced impact intensity of any event to system and explain the rate of recovery and rejuvenation (Scott et al. 2008). Besides that, Adger (2006) emphasises the need of vulnerability study to tourism as an effective analysis tool to explore the vulnerable level to hazards, inefficiency and marginality of both social and physical system and act as a guide for analysis of measures to improve wellbeing through risk reduction activity or program.

\subsection{Tourism Sensitivity to Disasters}

Turner et al. (2003) particularly construct a vulnerability analysis in sustainability sciences which enhance sustainability through the dimension synergy within it, namely Exposure, Sensitivity, Resilience. Adoption of Turner vulnerability analysis framework in the tourism context has been recognised (Vogel and O'Brien 2004). Becken et al. (2014) also emphasised the ability of the Turner framework to identify existing hazards in the tourism system and hazards outside their system. Specifically, Sensitivity element is one of the 
main dimension that forms vulnerability (Adger 2006). Clark et al. (2000) explain sensitivity is the degree to which a group or community or member is affected due to exposure to any set of stress. Sensitivity also defined as one level of the system is modified or affected by interference (Adger 2006). Sensitivity is a milestone for system improvement and rejuvenation in the next cycle. Gallopin (2006) argues that sensitivity is responsible to open the system to threats. In contrast, insensitive systems may not adapt to new situations and unable to seize presented opportunities. Besides, sensitivity is also influenced by social system strength and weakness (Calgaro et al. 2014), such as system ability to handle the changes in their circumstances that are not just determined based on the magnitude of the shock and stress (Lee 2014).

For instance, in the tourism context, sensitivity consists of an interactive relationship that determines the fragility of the tourism resort environment closely linked to the level of resource sensitivity to environmental changes caused by human and natural stress (Petrosillo et al. 2006). Sensitivity also can be seen based on the damage of destination image due to disaster. Chacko and Marcell (2008) affirmed that the destination image's fragility is genuinely affected by shock and stress. Indeed, the damage of both image and reputation is also related to the disaster itself and the misleading negative publicity (Ichinosawa 2006). Whenever a destination image is affected by negative perception, it is difficult for that destination to return competitively in a highly competitive tourism market (Knox and Marston 2004).

\subsection{Tourism Sensitivity Analysis Framework}

In general, Baker and Coulter (2007) and Cioccio and Michael (2007) argue on the Power of both perception and experience of the actors to influence different action and inaction including information accessibility, experience, personal characteristics and value consideration, ideologies, cultural environment and economy. Bird et al. (2010) added personal characteristics to influence perception and evaluation towards hazard including emotion sensitivity and attitude towards hazard consciously and unconsciously, level of hazard control, trust, values, gender, knowledge and anticipation, direct and indirect experience, and reliability of authority reports. Community perception on hazards also can be strengthened or weakened by the simultaneous dissemination and interpretation of risk through various social channels including individual, group community, media and institutions (Kasperson et al. 2012). This indicates by understanding the narrative of actors that could comprehensively comprehend the vulnerability mechanism of tourism, including their sensitivity towards natural disasters.

Particularly, Matusin et al. (2019) has come out with a Vulnerability Framework for Sustainable Tourism Development (VFSTD) with aim to determine the vulnerability of a tourism destination affected by a natural disasters or hazards towards sustainability (Figure 2.0). Importantly, the significance of VFSTD is the incorporation of two drivers; Power and Source as the fulfilment of human-environment relationship in determining the tourism vulnerability. In fact, both drivers are the catalyst for vulnerability (Birkmann 2006). In this context, Source refers to the place- and system-specific which characterised by the population (Adger 2006). On the other hand, Power is considered as social capacity used by individual, networks or organisation to control or manipulate the actions (Howitt, 2001). For VFSTD, Source referred to as tourism resources and Power as social capital which both elements contextualised as human-environment interaction (Matusin et al. 2019).

In the context of vulnerability analysis, Source is a specific place- and system, dynamic and varied, high scale, character of population, facing various stress and capacities to response and change constantly (Adger 2006). In tourism context, production or preparation of tourism product is influenced by destination image that embraces the interaction between multi-stage of enterprise and service including facilities, guides, marketing, operations and life spans that occur at multilevel (Dredge \& Jenkins 2003). In the perspective of VFSTD, the contextualisation of tourism as Source element is significant, especially in community-based tourism as their products are characterised by their destination 
image (Matusin et al. 2019). In addition, destructive events such as natural disasters also affect tourists' perception of actual situation or anticipation of safety risks (Ritchie 2008). Baker and Coulter (2007) emphasised that if there was no adjustment to reduce the vulnerability in tourism, it should not be a driver for sustainable tourism. Thus, natural disaster management becomes a vital component in sustainable tourism (Matusin et al. 2020). Therefore, VFSTD recapitulate items of Source such as Size of Business, Tourism Products, Duration Operation and Tourism Disaster Management (Matusin et al. 2019).

Power element in VFSTD is contextualised through social capital including bonding social capital, bridging social capital and linking social capital. Basically, social capital shaped by structure of relationship within social relationships (Coleman 1988) that benefit individuals and groups (Liu et al. 2014). The basic idea of social capital, including family members, friends, allies, or groups, becomes crucial assets during a crisis (Portes 2000). In the tourism perspective, social capital is a stronghold for tourism destinations to deal with catastrophe (Hwang \& Stewart 2017). Social capital is capable of providing a valuable theoretical perspective to the adaptation mechanism study and tourism community resilience (Guo et al. 2018). Social capital also has been emphasised as a vital component for sustainable tourism development (Taylor 2017; Dickinson et al. 2017) and foundation for collaboration success and governance efficiency towards sustainable tourism (Nunkoo 2017). In natural disaster perspective, social capital is critical in post-disaster recovery process for tourism destinations through three mechanism; bonding, bridging, linking (Szreter \& Woolcock 2004). Basically, bonding social capital referred as strong internal relationship within emotionally connected individuals such as family members and relatives (Ruiu et al. 2017). While bridging social capital is defined as external relationship among different individuals, including neighbourhoods or other tourism operators (Guo et al. 2018). Lastly, linking social capital can be understood as a vertical network that reflects the relationship of trust in a particular jurisdiction and mobilises the resource and Power (Poortinga 2012). Therefore, Matusin et al. (2019) enumerate three items represent Power in VFSTD; bonding, bridging and linking social capital.

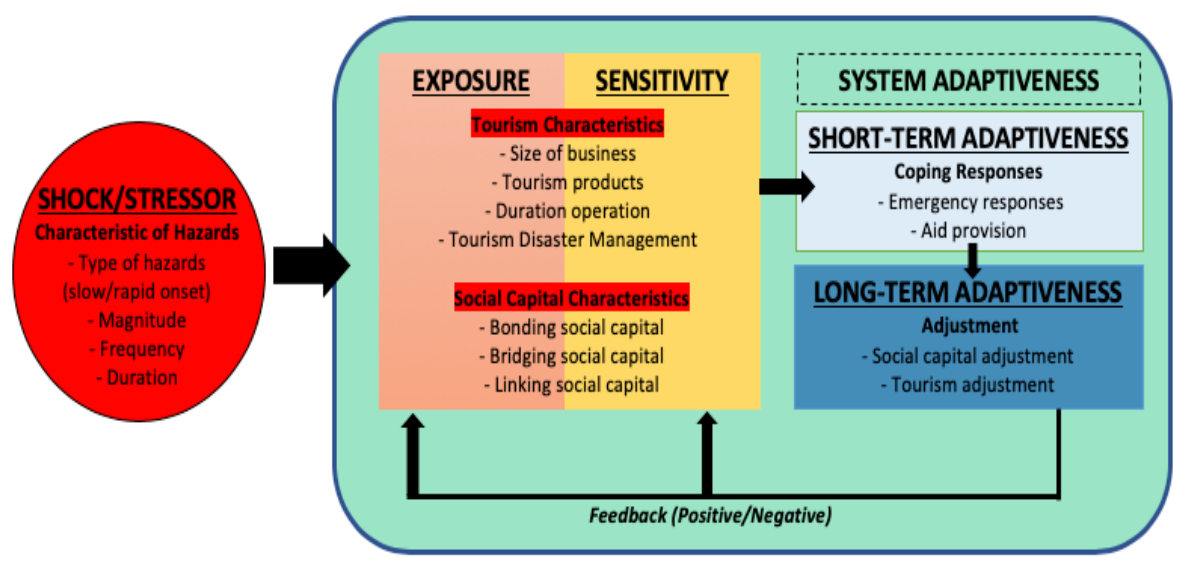

Figure 2: Vulnerability Framework for Sustainable Tourism Development 
Based on that, this study focuses on the adaptation of VFSTD, especially the Sensitivity element. Empirically, Matusin et al. (2020) has showed the adaptation of Exposure component of VFSTD, which revealed the significant exposure of tourism towards natural disasters by $51 \%$ in the case of Ranau earthquake 2015. However, Sensitivity component of VFSTD still needs to be tested empirically. Therefore, to fill the gap, the objective of this study is to determine the sensitivity of tourism towards natural disaster applying Sensitivity component of VFSTD. Figure 3.0 shows the adaptation of Sensitivity of VFSTD that entail two vital vulnerability drivers; Power and Source.

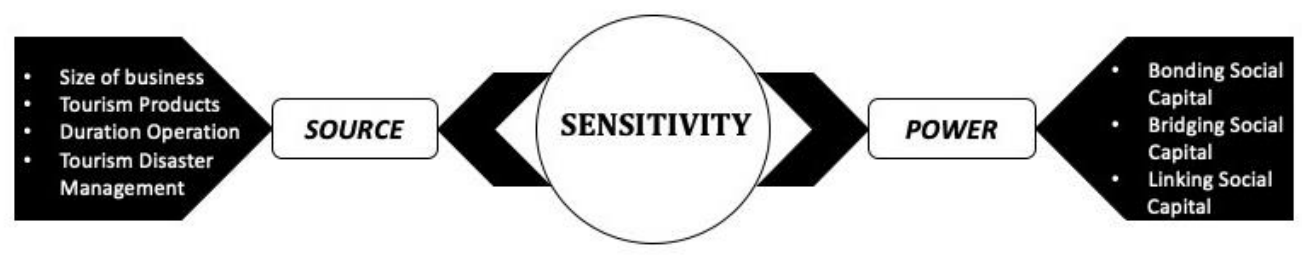

Figure 3: Sensitivity Framework of VFSTD

\section{Methods}

This study highlights constructivism that posits interactions occur within the world physical and human surrounding it and illuminated technically through social science research (Blaikie 2010). Creswell (2014) emphasises the tendency of constructivist to build on a definition that more subjective crafted based on their experience, in turn, motivate them to explore a subject more widely rather than narrowing it into specific categories. Therefore, this study applied qualitative methodology with a case study in order to understand the meaning of individual and group under study (Creswell 2014). The rationale of qualitative approach is the its ability to derive the results to understand a small phenomenon but well-known or to obtain deeper data that might be difficult to quantity through quantitative study or to gain new perspectives on something already publicly known (Maxwell 2005).

\subsection{Data collection}

This study's location was conducted in the area of Ranau-Kundasang which most affected tourist destination following the Ranau earthquake 2015 (USGS 2015; Felix Tongkul 2015). This study targeted tourism entrepreneurs or managers in the study areas through the combination techniques of purposive and snowball sampling. Purposive sampling is a selection technique that meets respondent criterion. In contrast, snowball sampling is applied to expand respondent selection with similar criteria through the suggestion of previous respondents (Chua, 2014). In congruence with study aim, an in-depth and semistructured interview technique (face-to-face) was applied. This technique is useful to obtain rich and substantively meaningful data (Campiranon \& Scott 2014). Data collection began from early September until end of October 2018. There were 30 participants 
involved in the interview after the sampling reached saturation point (no new information provided from new respondents). Increasing the number of respondents would not improve the quality of research findings (Matusin et al. 2020), if the research goal is to interpret a shared perception, belief or behaviour among relatively homogenous group (Guest et al. 2006).

\subsection{Data analysis}

This study applied a verbatim transcript to analyse the qualitative result. The thematic analysis was executed to organise the data manually, as this technique is a fundamental qualitative data analysis (Braun \& Clarke 2006). The foundation template of thematic analysis of this study was based on the vulnerability drivers of Source and Power incorporated under Sensitivity component. The template navigated the sequence of findings accordingly. To increase the validity of this study, Creswell (2014) recommends to provide the direct quotes and thick descriptions to convey a set of detailed findings. The reliability of qualitative data of this study was by having consistent research approach across different stages (Creswell 2014). Particularly, this study adopted procedure of thematic analysis by Braun and Clarke (2006) that comprised six basic phases; (1) familiarising the data, (2) initial coding, (3) searching for themes, (4) reviewing themes, (5) defining and naming themes and (6) producing report.

\section{Results}

Findings and discussions are presented based on Power and Source items as aforementioned. Figure 4.0 depicts the overall results of thematic sensitivity analysis of Ranau tourism towards earthquake 2015. Based on the thematic diagram below, each controlled variables of both Power and Source producing at least one to four subthemes. For Source, there are about nine subthemes produced - Tourism Product (Response, Attraction, Booking, Income), Size of Business (Staff, Facility), Duration Operation (Development), Disaster Management (Trauma, Chaos). For Power, there are five subthemes produced - Bonding (Relationship, Cooperation), Bridging (Participation), Linking (Collaboration, Research). 


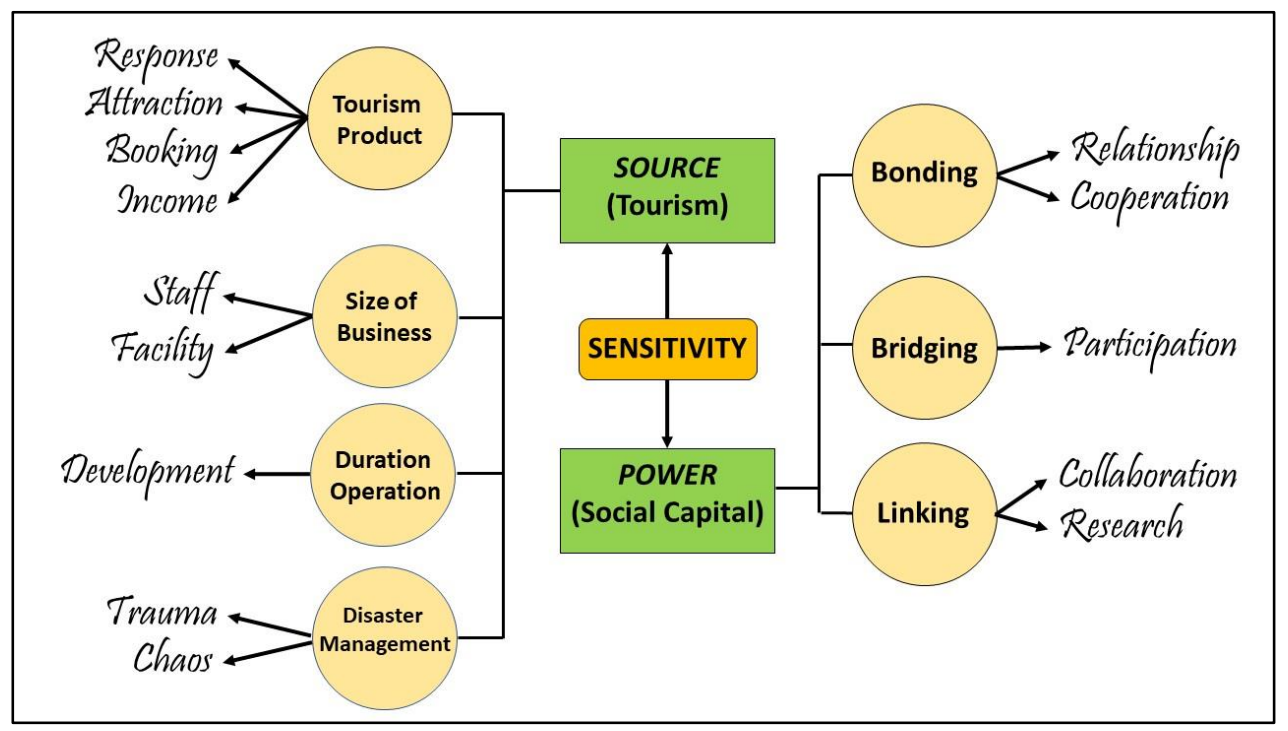

Figure 4: Sensitivity of Ranau Tourism towards 2015 earthquake

\subsection{Source of Ranau tourism}

\section{i. Tourism Product}

There are four subthemes created under Tourism Product; Response, Attraction, Booking, Income. This controlled variable explains the sensitivity of Ranau Tourism in the context of tourism products. For subtheme Response, it revealed the impairment of tourist arrival; tourists fear and natural attraction damage. All respondents exposed their fear and worries to visit Ranau following the earthquake, especially the Kinabalu Mount area (the epicentre). Consequently, the number of tourists' arrival in Ranau-Kundasang dropped sharply within three to six months after the earthquake. The situation is exacerbated by spreading of negative images of Ranau destination due to earthquake from the mainstream media and social media. It was stated that: "after the earthquake, we lost our tourists. There is almost no tourist come within this six months, the place becomes quite. They feel scared to come here" (R18-KD). The statement is supported by the arrival of the visitor report of Kinabalu Park that shows a tremendous gap in 2015 compared to the previous year - 103,359 visitors gap (Table 1). Figure 5 shows the damage of nature along the climbing trail in Kinabalu Mountain due to the earthquake.

Table 1: Number of visitors to Kinabalu Park (2012-2015)

\begin{tabular}{ccccc}
\hline Year & $\mathbf{2 0 1 2}$ & $\mathbf{2 0 1 3}$ & $\mathbf{2 0 1 4}$ & $\mathbf{2 0 1 5}$ \\
\hline $\begin{array}{c}\text { Number } \\
\text { of visitors }\end{array}$ & 285466 & 332838 & 314139 & 210780 \\
\hline
\end{tabular}

Second subtheme under Tourism Product is Attraction. This subtheme describes the destruction of nature attraction especially in the area of Ranau-Kundasang. Some of the damages include destruction of river stream that used as Tagal (local fish massage), the fallen of mountain rocks, and secondary effect such as mud flood. Following respondent stated: "all the rocks have fallen crashing the vegetation. Even now it can be seen the effects of notches on the mountain walls" (R13-KD). The secondary photo below shows the destruction of the climbing trail of Mount Kinabalu that caused by the fallen rocks from the peak of the mountain 


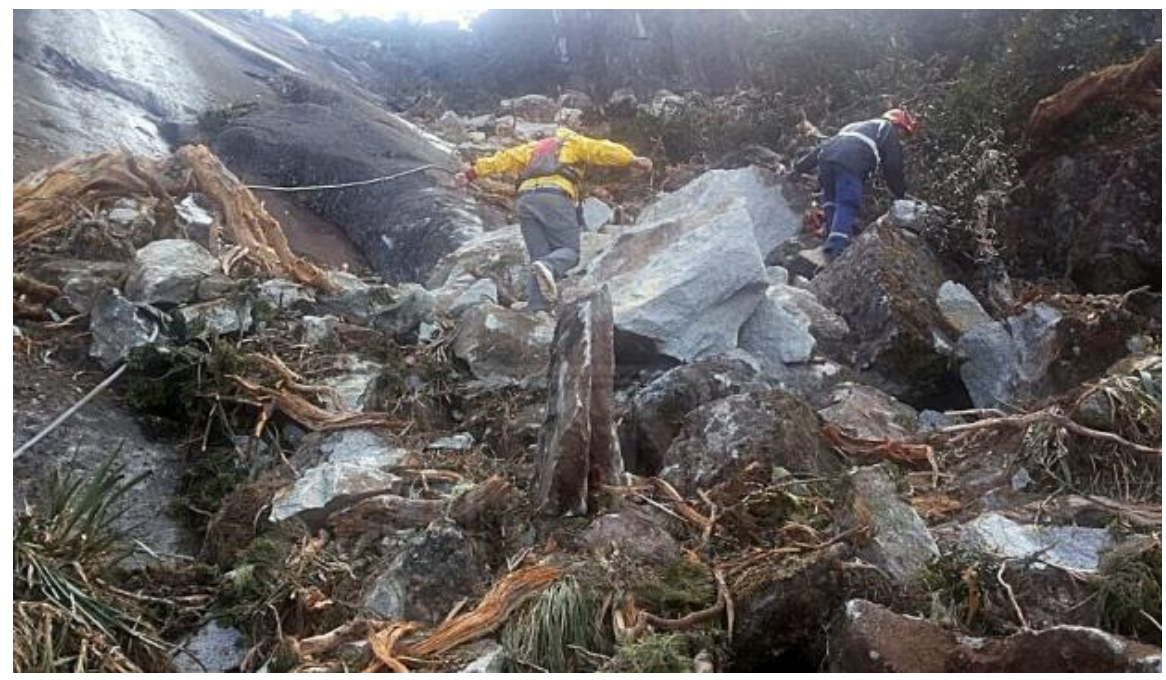

Figure 5: Damage of Nature Trail of Mount Kinabalu due to Earthquake 2015

The third subtheme under Tourism Product is Booking. This subtheme explains the cancellation of tourists booking including accommodation and travel package to Ranau after the earthquake hits this area. All respondents who provide accommodation in Ranau receive the cancellation right after the earthquake strike Ranau-Kundasang area. Few respondents have mentioned that some of their customers changed the date of booking. It was stated as follow: "after the earthquake strikes, all the customers cancelled their booking. No one is coming after that for about three months" (R27-KD).

The last subtheme under Tourism Product is Income which describes how the earthquake is affecting the respondents' income generation. Majority of the respondents are small-scale tourism operations, and their income generation is totally affected due to booking cancellation and no visit or tourism activity conducted after the earthquake. Some of them also need to return the payment to the customer once they had cancelled their booking. One of the respondent stated that: "our income drops, no activity conducted at all. No one is coming" (R14-KD).

\section{ii. $\quad$ Size of Business}

Under controlled variable of Size of Business, there are two subtheme produced; Staff and Facility. Generally, these controlled variables describe Ranau tourism's sensitivity in the context of their business size due to earthquake. For staff, this subtheme demonstrates the sensitivity faced by Ranau tourism operators' staff following the 2015 earthquake. Holistically, all the respondents affirm that all their staff are still staying work with them and continue their activities. In other words, the disaster did not affect the number of staff and labour force capacity. It was explained that: "all our staffs still with us. They continue their works as usual even after the strike. It just few additional work need to be done to repair the damage" (R12-KD).

The second subtheme is Facility, which describes Ranau Tourism's sensitivity following the earthquake in the context of facility. Based on the interview, most respondents mention that some of their facilities are damaged. The damages were included the cracks on the wall and floor of the premises, water pipe leaking especially toilet, and all respondents facing the worst water shortage after the earthquake. It was stated: "we lost our clean water supply after the earthquake. Our water catchment severely affected due to mud flood. Waterpipe is leaking, and the walls and floor are cracked" (R28-RN). Figure 6 shows the accommodation cracks of Dream World Resort Kundasang. This image was provided by one of the respondents due to earthquake strike. 


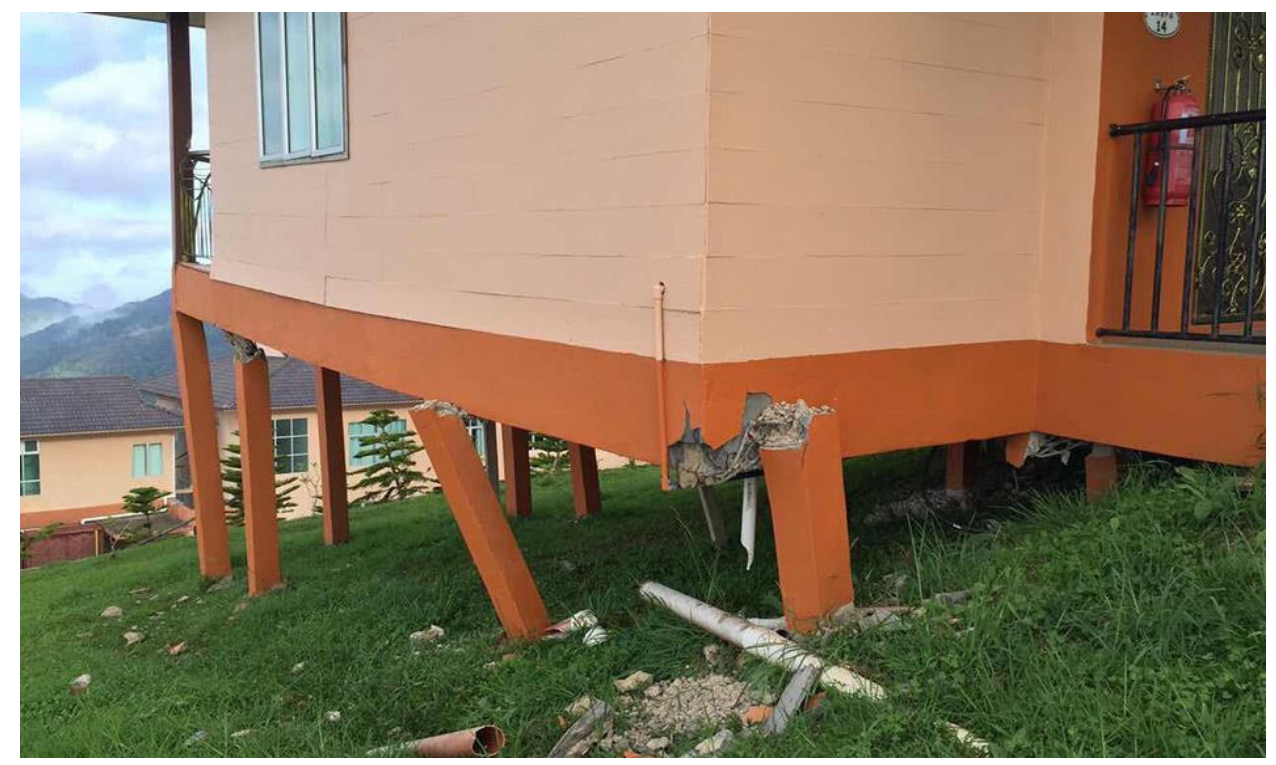

Figure 6: Cracks on room pillar of Drean World Resort Kundasang

\section{iii. Duration Operation}

The third controlled variable of Source is Duration Operation which only has one subtheme; Development. The subtheme explains the sensitivity of Ranau tourism development towards the 2015 earthquake. Majority of the respondents details the situation of their development activities at that year (2015) which need to be stopped for a while. This development activity of Ranau tourism are heavily affected from the sensitivity of tourism product and size of business variables as discussed early which exacerbate the development activities. The respondent stated that: "we are in progress to build another room for our accommodation, everything is smooth until we are hit by the earthquake. We need to stop the works due to many challenges" (R13-KD).

\section{iv. Natural Disaster Management}

The last controlled variables under Source is Disaster Management that produced two subthemes; Trauma and Chaos. This variable describes the sensitivity of Ranau tourism due to this disaster in the context of disaster management. The first subtheme is Trauma that explains the traumatic response of all respondents due to the earthquake. The 2015 earthquake is their first time experience with such disaster and the strongest earthquake recorded in Malaysia since 1972. Thus, they are in fear and worry at that time. This respondent share their experience: "at first the moment of earthquake, we are all screaming out due to fear. Our houses are shaking vigorously, that we think it will going to collapse" (R20-KD). The last subtheme is Chaos. It explains all respondents' chaotic situation because they never expect an earthquake would strike their area and at sudden, it strike theirs at strong magnitude. At that time, they have no idea what to do and how to handle the situation. Following respondent explained that: "we are running out from our office that time, out from our building. We are terrified. Everyone is left with confusion, and it hard to believe it was an earthquake hit us" (R13-KD).

Overall, Ranau tourism's sensitivity due to 2015 earthquake can be categorised into two situation; affected and unaffected components. The affected components, including tourist's arrival drops, damages of nature environment and tourism facilities, booking cancellation, downturn of income, development activities postponed as well as traumatic and chaotic situation of respondents. While, unaffected Source of Ranau tourism including staff capacity. Therefore, the score of Ranau tourism sensitivity is enumerated as follow (Table 2). The subthemes score is based on its characteristics (affected and unaffected). Based on the Table 2, Tourism Product, Duration Operation and Natural Disaster 
Management of controlled variables are considered as high level of sensitivity, while Size of Business shows moderate level of sensitivity. Therefore, the sensitivity of Ranau tourism Source is $92 \%$, a significant percentage of sensitivity level.

Table 2: Score of Ranau Tourism Sensitivity

\begin{tabular}{|c|c|c|c|}
\hline $\begin{array}{c}\text { Controlled } \\
\text { Variables }(\mathrm{CV})\end{array}$ & Subthemes & Characteristics & $\begin{array}{l}\text { Sensitivity } \\
\text { Level of CV }\end{array}$ \\
\hline \multirow[t]{4}{*}{ Tourism Products } & Response & Affected & \multirow[t]{4}{*}{ High } \\
\hline & Attraction & Affected & \\
\hline & Booking & Affected & \\
\hline & Income & Affected & \\
\hline \multirow[t]{2}{*}{ Size of Business } & Staff & Unaffected & \multirow[t]{2}{*}{ Moderate } \\
\hline & Facility & Unaffected & \\
\hline Duration Operation & Development & Affected & High \\
\hline \multirow{2}{*}{$\begin{array}{l}\text { Natural Disaster } \\
\text { Management }\end{array}$} & Trauma & Affected & \multirow[t]{2}{*}{ High } \\
\hline & Chaos & Affected & \\
\hline \multicolumn{4}{|l|}{ Calculation Score } \\
\hline Level & Score & Overall Score & 12 \\
\hline Low & 1 & Source Score & $3+2+3+3=11$ \\
\hline Moderate & 2 & Sensitivity & \\
\hline High & 3 & $\begin{array}{l}\text { Percentage } \\
\text { (Source) }\end{array}$ & $92 \%$ \\
\hline
\end{tabular}

\subsection{Power of Ranau Tourism}

This part describes the sensitivity of Ranau tourism towards the 2015 earthquake in the context of Power (social capital). Based on the thematic data in Figure 4, Bonding variable producing two subthemes; Relationship and Cooperation. For relationship, it explains the sensitivity of Ranau tourism in the context of inner relationship. Based on the interview, all the respondents confirmed that their bonding among the staff of their enterprise is still strong and unaffected at all aftermath. It was stated that: "the earthquake is not an interruption for our relationship and communication. Nothing change after all" (R4-RN). The second subtheme is cooperation. It basically describes the sensitivity of Ranau tourism cooperation due to this situation. Indeed, all respondents claim that the cooperation from the staff and among themselves is kept strong, instead they are helping each other that in need after the earthquake. This respondent informed that: "all our staff stay together during the disaster. They helps each other voluntarily" (R17-KD).

For Bridging variable, it describes the sensitivity of relationship among tourism community in Ranau. Thematic data shows one subtheme under this controlled variable which is Participation. The subtheme explains to what extend the earthquake could affect the participation of tourism community in Ranau. Particularly, most of the respondents involved in any tourism platform or organisation confirmed that their participation at the local level is not affected at all due to earthquake. Instead, they held meetings among the tourism community or organisation frequently compare before the disaster strike. It was mentioned: "most of our members still conducting their program and activity, do more meeting, and it became more frequent after the earthquake. We discuss many things on how to recover our tourism and business aftermath" (R8-KD).

The last controlled variable of Power is Linking, which describes the sensitivity of Ranau tourism networking and relationship with stakeholders in the 2015 earthquake. There are two subthemes formed; Collaboration and Research. For collaboration, it details Ranau tourism's sensitivity in terms of collaboration with stakeholders during the disaster. Based on the interview, all the respondents agreed that their collaboration with government agencies is unaffected during the disaster, instead it been strengthened even more. This mentioned as follow: "it can be said that every week we have visited by ministry of tourism to monitor the issues here after the earthquake" (R24-KD). 
However, some of the collaboration with tourism agencies is affected due to this disaster because of the booking cancellation of their tourism package in Ranau. At the same time, Ranau tourism also has to close their activities temporarily to allow recovery processes. It was stated that: "after the earthquake, the tourism agencies cancelled their trip to Ranau and changed to other destination. All because they are scared to come here" (R20-KD). The last subtheme is research, which elaborates the sensitivity of research-related activities involving the Ranau tourism community. A few respondents involved with research from local university explained that the activity need to be postponed because a few research sites is closed temporarily due the impact of earthquake until it becomes safe to be visited by the researchers. The respondents explained that: "any study or research at that time we have to stop for a while due to safety factor" (R3-KD).

Overall, the sensitivity of Power of Ranau tourism due to 2015 earthquake also can be categorised into two characteristics; affected and unaffected. Any impairment occurred to the Ranau tourism of Power component is considered as affected such as collaboration and research, while components like relationship and cooperation that still maintained are considered as unaffected. Table 3 enumerated the score of Power sensitivity of Ranau tourism. Based on the table, the sensitivity of Power or social capital of Ranau tourism is considered as insignificant with only $44 \%$. The Bonding and Bridging show low level of sensitivity, while Linking is under moderate condition. Therefore, the score of Ranau tourism sensitivity collectively (combination of Source and Power) is $68 \%$ (Table 4). This shows that Ranau tourism has a significant sensitivity towards the 2015 earthquake.

Table 3: Score of Ranau Tourism Sensitivity - Power

\begin{tabular}{lccc}
$\begin{array}{c}\text { Controlled } \\
\text { Variables } \\
(\mathbf{C V})\end{array}$ & Subthemes & Characteristics & $\begin{array}{c}\text { Sensitivity } \\
\text { Level of } \\
\text { CV }\end{array}$ \\
\hline Bonding & Relationship & Unaffected & Low \\
\cline { 2 - 3 } & Cooperation & Unaffected & \\
\hline Bridging & Participation & Unaffected & Low \\
\hline Linking & Collaboration & Unaffected & Moderate \\
\cline { 2 - 4 } & Research & Affected & \\
\hline Calculation Score & Score & Overall Score & \\
\hline Level & 1 & Power Score & \\
\hline Low & 2 & Sensitivity & \\
\hline Moderate & 3 & $\begin{array}{l}\text { Percentage } \\
(\text { Power })\end{array}$ & $\mathbf{4 4 \%}$ \\
\hline High & & & \\
\hline
\end{tabular}

Table 4: : Collective Score of Ranau Tourism Sensitivity

\begin{tabular}{lcc}
\hline Component & Sensitivity & Overall Percentages \\
\hline Source & $92 \%$ & $68 \%$ \\
Power & $44 \%$ & \\
\hline
\end{tabular}




\section{Discussion}

Based on the result elaborated, the main keywords of sensitivity for Tourism Product is the downturn of income generation of Ranau tourism after the earthquake strike. This is the indirect impact of the deterioration of the tourism destination image of Ranau and the natural attraction including Mount Kinabalu. Tourists' arrival dropped tremendously and exacerbated by booking cancellation by them. This is due to negative perception towards Ranau affected by the disaster and the feel of fear from the outsiders. Chacko and Marcell (2008) agreed that the fragility of tourist destination can be influenced by the shock or pressure strike the area. The deterioration of destination image can be triggered through the disaster itself and negative publication that confusing other people (Ichinosawa 2006). Thus, the tourist chooses not to visit the place because they feel insecure or due to any negative feedback of the place (Scott et al. 2008). Ultimately, tourism operation need to be closed or shut down for months which affects the tourism community (Kato 2017) including Ranau tourism in this context.

For the size of business, this study main explain the damages of tourism facilities in Ranau due to the earthquake. It directly related to the magnitude of Ranau earthquake (scale VII, 6.0 magnitude) and the fragility of mountainous area in Ranau. Both characteristics exacerbated the damages of facility in the area after strike by the huge tremor. The development of tourism in sensitive area such as Ranau is common due to its geographical uniqueness that hard to be find in low land area. Jodha (1991) also describes that mountainous areas have accessibility, difficulty, and diversity ecologically. Indirectly, these characteristics become main attraction and also challenges to nature tourism activity (Nyaupane and Chhetri 2009). Petrosillo et al. (2006) also explained that sensitivity principally has interaction between the environment and the resources towards the changes caused by human pressure or nature itself. Therefore, the magnitude damages of Ranau tourism facilities due to the earthquake can be triggered by many factors internally and externally.

Consequently, the sensitivity of both tourism product and business size have stunted the development activities of Ranau tourism during the disaster. They have to focus recovery process or activities (multitasking and finance), alternately postponing the development activities that are on schedule due to workforce and money limitation. About $80 \%$ of the respondents are private tourism operators that only have small capacity scale and have limited resources compared to large tourism operators (20\% of respondents) that might have back up or contingency plan for recovery activities. The recovery process becomes more difficult when all the respondents do not have particular natural disaster management their development, which leads them into traumatic situations during the disaster. This is largely influenced by the disintegrated natural disaster management or disaster risk reduction into national and local sustainable tourism development agendas. Thus, the lacking of this integration has forced Ranau tourism into chaotic condition in this context.

Ranau tourism has shown low sensitivity level for Power or social capital sensitivity due to 2015 earthquake for all controlled variables (Bonding, Bridging, Linking). This can be reflected through low exposure level of Ranau tourism due to this natural disaster as discussed by Matusin et al. (2020). The influence of exposure towards sensitivity element is the fundamental relationship that becomes a domain to system vulnerability. Clark et al. (2000) revealed that sensitivity as measurement level of how a group or a community being affected due to their exposure to any set of pressure. Indeed, sensitivity also influenced by strengths and weakness of social system (Calgaro et al. 2014). Holistically, this study has confirmed how both element of Exposure and Sensitivity are related to each other and importantly the role of sensitivity element to open the improvement of Ranau tourism in many aspect in dealing the vulnerability. Ultimately, it "knock" the system (Ranau tourism) into consciousness about their weakness or fragility towards shock or uncertainty and to what extend they would able to handle them. 


\section{Conclusion}

Tourism is one of the biggest economic sectors that enhance development activity, including Malaysia and particularly Ranau, Sabah. The earthquake in 2015 unfortunately strike Ranau with strong magnitude of 6.1, the strongest earthquake recorded in Malaysia. This raise the question on how tourism sensitivity is addressed at the destination level. Hence, this study aimed to apply the case study of Ranau earthquake 2015 to explore tourism sensitivity towards natural disasters. A qualitative method is executed to determine the thematic data by using the Sensitivity component mechanism from VFSTD. 30 respondents of tourism operators in Ranau have been interviewed via purposive and snowball sampling. The results show that Source of Ranau tourism is significantly sensitive towards the earthquake compare to Power component. Collectively, the combination of both components leads to Ranau tourism into a significant level of sensitivity. Therefore, it indicates the relationship between internal and external factors that influence Ranau tourism sensitivity towards 2015 earthquake. Importantly, it shows how Ranau tourism's exposure influenced their sensitivity and ultimately produced the vulnerability of the system.

Acknowledgments: This research publication was funded by UTM Transdisciplinary Research Grant No. Q.J130000.3552.07G55.

\section{References}

1. Adger, W. N. 2006. Vulnerability. Global Environmental Change 16(3): 268-281.

2. Adger, W. N. 2008. Resilience and Vulnerability. Dlm. Leach, M. (eds). Re-framing Resilience: A Symposium Report, pg. 5-7. Brighton: STEPS Centre.

3. Baker, K. \& Coulter, A. 2007. Terrorism and tourism: the vulnerability of beach vendors' livelihoods in bali. Journal of Sustainable Tourism 15(3): 249-266.

4. Becken, S., Mahon, R., Rennie, H. G. \& Shakeela, A. 2014. The tourism disaster vulnerability framework: An application to tourism in small island destinations. Natural Hazards 71(1): 955-972.

5. Berkhout, F. 2008. Order in socio-technical systems: The dark side of Resilience. In. Leach, M. (eds.). Re-framing Resilience: A Symposium Report, pg. 11-12. Brighton: STEPS Centre.

6. Bird, D., Gisladottir, G. \& Dominey-Howes, D. 2010. Volcanic risk and tourism in southern Iceland: Implications for hazard, risk and emergency response education and training. Journal of Volcanology and Geothermal Research 189: 33-48.

7. Birkmann, J. 2006. Measuring Vulnerability to Natural Hazards. Tokyo: United Nations University Press.

8. Blaikie, N. 2010. Designing social research 2nd edition. Cambridge: Polity Press.

9. Braun, V. \& Clarke, V. 2006. Using thematic analysis in psychology. Qualitative Research in Psychology 3: 77-101.

10. Calgaro, E. \& Lloyd, K. 2008. Sun, sea, sand and tsunami: Examining disaster vulnerability in the tourism community of Khao Lak, Thailand. Singapore Journal of Tropical Geography 29(3): 288-306.

11. Calgaro, E., Lloyd, K. \& Dominey-Howes, D. 2014. From vulnerability to transformation: a framework for assessing the vulnerability and resilience of tourism destinations. Journal of Sustainable Tourism 22(3): 341-360.

12. Campiranon, K., \& Scott, N. 2014. Critical success factors for crisis recovery management: A case study of Phuket hotels. Journal of Travel \& Tourism Marketing, 31(3), 313-326.

13. Chacko, H. E. \& Marcell, M. H. 2008. Repositioning a Tourism Destination: The Case of New Orleans After Hurricane Katrina. Journal of Travel \& Tourism Marketing 23(2): 223-235.

14. Chacko, H. E. \& Marcell, M. H. 2008. Repositioning a Tourism Destination: The Case of New Orleans After Hurricane Katrina. Journal of Travel \& Tourism Marketing 23(2): 223-235.

15. Chua, Y. P. 2014. Research Method (3rd Edition). Selangor: McGraw Hill Education.

16. Cioccio, L. \& Michael, E. J. 2007. Hazard or disaster: Tourism management for the inevitable in Northeast Victoria. Tourism Management 28(1): 1-11.

17. Clark, G., Jaeger, J. \& Corell, R. 2000. Assessing vulnerability to global environmental risks. Belfer Center for Science and International Affairs Discussion Paper 2000- 12. Environment and Natural Resources Program, Kennedy School of Government, Harvard University, Cambridge. MA. Available at http://ksgnotes1.harvard.edu/BCSIA/sust.nsf/pubs/pub1/\$File/2000-12.pdf

18. Clark, G., Jaeger, J. \& Corell, R. 2000. Assessing vulnerability to global environmental risks. Belfer Center for Science and International Affairs Discussion Paper 2000- 12. Environment and Natural Resources Program, Kennedy School of Government, Harvard University, Cambridge. MA. Available at http://ksgnotes1.harvard.edu/BCSIA/sust.nsf/pubs/pub1/\$File/2000-12.pdf

19. Coleman, J. S. 1988. Social capital in the creation of human capital. American Journal of Sociology 94: S95-S120.

20. Creswell, J. W. 2014. Research design: Qualitative, quantitative, and mixed methods approaches. Thousand Oaks, California: Sage Publications. 
21. Dickinson, J. E., Filimonau, V., Hibbert, J. F., Cherrett, T., Davies, N., Norgate, S., \& Winstanley, C. 2017. Tourism communities and social ties: The role of online and offline tourist social networks in building social capital and sustainable practice. Journal of Sustainable Tourism 25(2): 163-180.

22. Dredge, D. \& Jenkins, J. 2003. Destination place identity and regional tourism planning. Tourism Geographies 5(4): $383-407$.

23. Eakin, H. L. \& Luers, A. L. 2006. Assessing the vulnerability of Social-Environment Systems. Annual Review of Environment and Resources 31: 365-394.

24. Faulkner, B. 2001. Towards a framework for tourism disaster management. Tourism Management 22(2): 135-147.

25.

26

Felix Tongkul, Rodeano Roslee, Baba Musta, Ismail Abdul Rahim, Kawi Bidin, Hennie Fitria W.S. Erfen \& Mohamed Ali Yusuf Mohd.Husin. 2017. Perancangan pembangunan di kawasan berisiko gempa bumi: pembelajaran dari gempa bumi 5 Jun 2015 Ranau, Sabah. Dlm. Rodeano Roslee, Felix Tongkul, Efren, H. F. W., Hazerina Pungut \& Mohamed Ali Yusof Mohd Husin (pnyt.). Bencana Alam ke Arah Pengurusan Bencana Yang Mapan, In. 49-49. Universiti Malaysia Sabah: Pusat Kajian Bencana Alam (NDRC) Universiti Malaysia Sabah.

28. Felix Tongkul. 2015. The 2015 Ranau earthquake: cause and impact. Sabah Society Journal 32(2015): 1-28

29. Gallopin, G. C. 2006. Linkages between vulnerability, resilience, and adaptive capacity. Global Environmental Change 16(3): 293-303.

30. Guest, G., Bunce, A., \& Johnson, L. 2006. How many interviews are enough? An experiment with data saturation and variability. Field methods, 18(1): 59-82.

31. Guo, Y., Zhang, J., Zhang, Y. \& Zheng, C. 2018. Examining the relationship between social capital and community residents' perceived resilience in tourism destinations. Journal of Sustainable Tourism 26(6): 973-986.

32. Hay, A .2006. System. In. Johnston, R. J., Gregory, D., Pratt, G. \& Watts, M. (eds.). The Dictionary of Human Geography. 4th ed. Carlton: Blackwell Publishing.

33. Howitt, R. 2001. Rethinking resource management: justice, sustainability and indigenous peoples. London: Routledge.

34. Hwang, D., \& Stewart, W. P. 2017. Social capital and collective action in rural tourism. Journal of Travel Research, 56(1): 81-93.

35. Ichinosawa, J. 2006. Reputational disaster in Phuket: The secondary impact of the tsunami on inbound tourism. Disaster Prevention and Management 15(1): 111123.

36. Jodha, N. S. 1991. Mountain perspective and sustainability: A framework for development strategies, In. Banskota, M., Jodha, N. S. \& Pratap, U. (eds.). Sustainable Mountain Agriculture: Perspectives and Issues, In. 41-82. New Delhi: Oxford IBH.

37. Kasperson, J. X., Kasperson, R. E., Turner, B., Hsieh, W., \& Schiller, A. 2012. Vulnerability to global environmental change. Dlm. Kasperson, R.E., Kasperson, J. (eds.). The Social Contours of Risk: Volume II: Risk Analysis, Corporations and the Globalization of Risk, in. 245-285. London: Routledge

38. Kato, K. 2017. Debating sustainability in tourism development - resilience, traditional knowledge \& community, a post-disaster perspective. Tourism Planning and Development 3(11): 1-13.

39. Knox, P. L. \& Marston, S. A. 2004. Places and Regions in Global Context: Human Geography. New Jersey: Pearson Education.

40. Lee Y-J. 2014. Social vulnerability indicators as sustainable planning tool. Environmental Impact Assessment Review 44: $31-42$.

41. Liu, J., Qu, H., Huang, D., Chen, G., Yue, X., Zhao, X., \& Liang, Z. 2014. The role of social capital in encouraging residents' proenvironmental behaviours in community based ecotourism. Tourism Management 41:190-201.

42. Matusin, A. M. R. A., Siwar, C. \& Halim, S. A. 2019. Vulnerability framework of tourism to natural disasters. GEOGRAFIA 15(4):137-150

43. Matusin, A. M. R. A., Siwar, C., Halim, S. A. 2020. Assessment Of Tourism Entrepreneurs' Exposure To Natural Disasters: A Case Study Of Ranau Earthquake (2015). Journal of Sustainability Science and Management 15(8):167-190.

44. Maxwell, J. A. 2005. Qualitative Research Design: An Interactive Approach (2nd Ed). Thousand Oaks, California: Sage Publications.

45. Miller, F., Osbahr, H., Boyd, E., Thomalla, F., Bharwani, S., Ziervogel, G., \& Nelson, D. 2010. Resilience and vulnerability: Complementary or conflicting concepts? Ecology and Society 15(3): 11.

46. Nunkoo, R. 2017. Governance and sustainable tourism: What is the role of trust, power and social capital? Journal of Destination Marketing and Management 6(4): 277- 285.

47. Nyaupane, G. P. \& Chhetri, N. 2009. Vulnerability to climate change of nature-based tourism in the Nepalese Himalayas. Tourism Geographies 11(1): 95-119.

48. O'Brien, K. 2006. Editorial: Are we missing the point? Global environmental change as an issue of human security. Global Environmental Change 16: 1-3.

49. Orchiston, C. 2012. Seismic risk scenario planning and sustainable tourism management: Christchurch and the alpine fault zone, South Island, New Zealand. Journal of Sustainable Tourism 20(1): 59-79.

50. Petrosillo, I., Zurlini, G., Grato, E. \& Zaccarelli, N. 2006. Indicating fragility of socio ecological tourism-based systems. Ecological Indicators 6: 104-113.

51. Poortinga, W. 2012. Community resilience and health: The role of bonding, bridging, and linking aspects of social capital. Health \& Place, 18(2): 286-295.

52. Portes, A. 2000. The Two Meanings of Social Capital. Sociological Forum 15(1): 1- 12.

53. Ranau District Department. 2011. Pelancongan Daerah Ranau http://ww2.sabah.gov.my/pd.rnu/pelancongan.html [12 Jun 2018] 
54. Ranau District Department. 2015. Taklimat Pembangunan Daerah Ranau. Slaid. Daerah Ranau: Pejabat Daerah Ranau.

55. Rigg, J., Grundy-Warr, C., Law, L. \& Tan-Mullins, M. 2008. Grounding a natural disaster: Thailand and the 2004 tsunami. Asia Pacific Viewpoint, 49(2): 137 - 154.

56. Ritchie, B. W. 2008. Tourism disaster planning and management: From response and recovery to reduction and readiness. Current Issues in Tourism 11(4): 315-348.

57. Ruiu, M. L., Seddaiu, G., \& Roggero, P. P. 2017. Developing adaptive responses to contextual changes for sustainable agricultural management: The role of social capital in the Arborea district (Sardinia, Italy). Journal of Rural Studies, 49: 162-170.

58. Sabah Park. 2018. Logo, Mission, Vision and Goals. http://www.sabahparks.org.my/index.php/about-us/logo-vision-mission objective-goals [12 September 2018]

59. Scott, N., Laws, E. \& Prideaux, B. 2008. Tourism Crises and Marketing Recovery Strategies. Journal of Travel \& Tourism Marketing 23(2):1-13.

60. Szreter, S. \& Woolcock, M. 2004. Health by association? Social capital, social theory, and the political economy of public health. International Journal of Epidemiology, 33(4): 650-667.

61. Taylor, S. R. 2017. Issues in measuring success in community-based Indigenous tourism: Elites, kin groups, social capital, gender dynamics and income flows. Journal of Sustainable Tourism 25(3): 433-449

62. Town and Regional Planning Department of Sabah. 2016. Pelan Struktur Negeri 2033. Kota Kinabalu: Jabatan Perancangan Bandar dan Wilayah Negeri Sabah

63. Tsai, C. H. \& Chen, C. W. 2010. An earthquake disaster management mechanism based on risk assessment information for the tourism industry-a case study from the island of Taiwan. Tourism Management 31(4): 470-481.

64. Tsao C-Y \& Ni C-C .2016. Vulnerability, resilience, and the adaptive cycle in a crisis prone tourism community. Tourism Geographies 18(1): 80-105.

65. Turner, B. L., Kasperson, R.E., Matson, P.A., McCarthy, J.J., Corell, R.W., Christensen, L., Eckley, N., Kasperson, J.X., Luers, A., Martello, M.L., Polsky, C., Pulsipher, A. \& Schiller, A. 2003. A framework for vulnerability analysis in sustainability science. Proceedings of the National Academy of Sciences 100(14): 8074-8079.

66. UNIDSR 2017. Terminology on Disaster Risk Reduction. https://www.unisdr.org/we/inform/terminology\#letter-v [15 Disember 2018]

67. United State Geological Survey. 2015. M 6.0 - 14km WNW of Ranau, Malaysia https://earthquake.usgs.gov/earthquakes/eventpage/us20002m5s/shakemap/in ensity [17 Mei 2018]

68. Vogel, C. \& O’Brien, K. 2004. Vulnerability and global environmental change: rhetoric and reality. AVISO - Informational Bulletin on Global Environmental Change and Human Security 13(3):1-8

69. World Tourism Organization. 2013. Sustainable tourism for development guidebook 2013. Madrid: UNWTO

70. World Tourism Organization. 2018. UNWTO Tourism Highlights 2018 Edition. Madrid: UNWTO. 